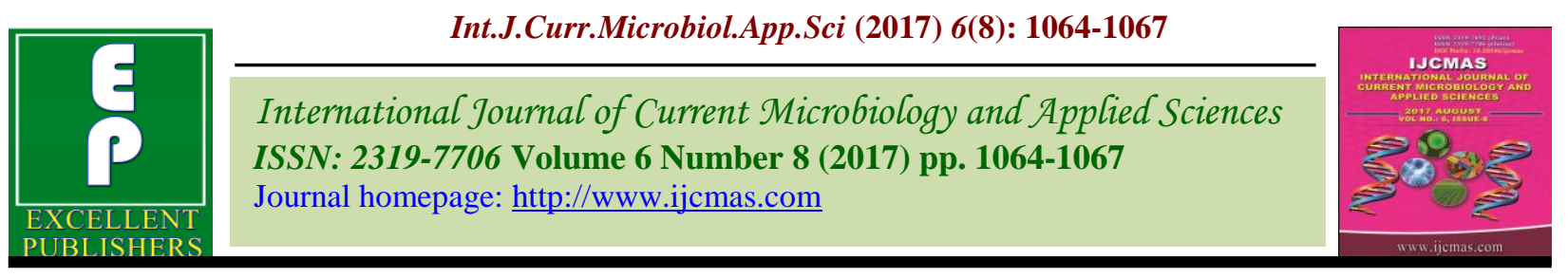

Case Study

https://doi.org/10.20546/ijcmas.2017.608.132

\title{
Problems of KVK (Krishi Vigyan Kendra) Beneficiaries in Adoption of Recommended Production of Wheat Crop
}

\author{
Vijay Kumar Verma, O.P. Yadav, A.K. Singh and Rajmani* \\ Department of Agricultural Extension, Chandra Shekhar Azad University of Agriculture and \\ Technology, Kanpur, Uttar Pradesh -208002, India \\ *Corresponding author
}

\section{A B S T R A C T}

\begin{tabular}{|c|c|}
\hline & \multirow{4}{*}{$\begin{array}{l}\text { The study was conducted in the purposively selected district Basti to analyze the } \\
\text { problems of K.V.K. beneficially in adoption of recommended production of } \\
\text { Wheat crop. On the basis of findings most of the farmers were having low level of } \\
\text { knowledge about improved variety, seed treatment and plant protection measures. } \\
\text { The majority of K.V.K. beneficiaries belonged to the age group of } 25 \text { to } 50 \text { year } \\
\text { and } 51.25 \% \text { who were growing wheat in study area. On the basis of findings the } \\
\text { adoption level of wheat production technology was found of medium level due to } \\
\text { more expensive technology. Appropriate technology is needed to the wheat } \\
\text { grower farmers. Poor level of knowledge and less profitable technology were the } \\
\text { major problems which create hindrances for adoption of wheat production } \\
\text { technology. }\end{array}$} \\
\hline & \\
\hline $\mathbf{A}$ & \\
\hline & \\
\hline
\end{tabular}

\section{Introduction}

The programme is related to modern agriculture technologies are being implemented by not just a single agency but also by other development department like this the extension department like the extension department of the agricultural, soil and water conservation forestry animal husbandry sericulture, state agriculture universities, local bodies like Zilapanchayat banking and financial institution private and co-operative bodies, nongovernmental organization and other farmers self help group. The present extension system incorporates the use of traditional method demonstration, kisanmela, field days, exhibitions, seminars, slide show, video shows, chart poster presentation, etc. India has produced the highest ever food grain of 264.38 million tonnes in 2013-14 surpassing the earlier record of 257.13 million tonnes archives in 2012-2013. In 2013-14 production of wheat + pulse production is also estimates to be on all time record at 115.42 million tonnes and 106.29 million tonnes respectively despite a setback in the production of rice due to drought in some of the major rice producing areas in the country food grows production reached the record level awing the significant improve in production of wheat, pulse coarse cereals. In 2013-14 the country produced 32.41 million tonnes of oil seeds and 19.57 million tonnes of pulses which had 
even closed the 18.34 million tonnes mark in the past apart from 106.29 million tonnes of rice and 95.85 million tonnes of wheat maize production was 24.19 million tonnes sugar cane 348.38 million tones and cotton 36.50 million tonnes. Agriculture also recorded as $5.1 \%$ growth-a first again-compared to the $4.4 \%$ growth achieved all these years, contributed by steady increase the production soybean 2.71 million tonnes oven its production during 20013-14.

\section{Research Methodology}

Formula- $A \cdot Q=\frac{\sum \mathrm{E} / \mathrm{P}}{\text { No ofyear }} \times 100$

Where on

$\mathrm{E}=$ Extent

$\mathrm{P}=$ Potentiality

The primary data were collected with the help of structured schedule through direct personal interview. The secondary data were collected from the district and block head quarter and journal etc. The statistical measures which have been used in this study include percentage and average.

\section{i-Percentage}

Simple comparison have made on the basis of the percentage. The frequency of a particular cell was multiplied by 80 and divided by the total number of respondent in that category to which they belonged. This has been used at most of the places in this thesis and has proved helpful in organizing data with clarity and precision.

$$
\text { Percentage }=\frac{\text { No. of respondents }}{\text { Total no. of respondents }} \times 100
$$

\section{Operational definition}

\section{KVK}

Krishivigyan Kendra has been conceived as vocational training institutions for practicing farmers, village youth, farm women, fisherman etc.

\section{Mass media exposure}

This includes exposure of the paper, literature, film and magazines etc.

\section{Research finding}

The problems of beneficiaries in adoption of recommended practices of wheat crop

Krish Vigyan Kendra trained farmer must be having some problem too. These problems must be verified and known the people concerned hence it was tried to make an assessment of the problems and intensity faced by the farmers.

Table.1 Problem faced by the beneficiaries

\begin{tabular}{|l|l|c|c|}
\hline Sl.No. & \multicolumn{1}{|c|}{ Particulars } & $\begin{array}{c}\text { No. of } \\
\text { respondents }\end{array}$ & Percentage \\
\hline 1. & $\begin{array}{l}\text { Poor knowledge of recommended } \\
\text { technology }\end{array}$ & 52 & 65.00 \\
\hline 2. & More expenditure and less profit & 50 & 62.5 \\
\hline 3. & Interest rate of bank loan & 44 & 55 \\
\hline 4. & Non availability of bank loan & 37 & 46.25 \\
\hline 5. & Problem of marketing & 40 & 50.00 \\
\hline 6. & Non availability of D.A.P. & 34 & 42.5 \\
\hline 7. & Un assured irrigation & 35 & 43.75 \\
\hline 8. & Problem of storage & 20 & 25.00 \\
\hline
\end{tabular}


It is evident from the table 1 that maximum trained farmers $(65.00 \%)$ were facing problem of poor knowledge of recommended technology followed by maximum trained farmer (62.5) were facing problem more expenditure and less profit, followed by maximum trainees farmers (55) were facing problem interest rate of bank loan, followed by maximum trained farmer $(46.25 \%)$ were facing problems non availability of bank loan followed by maximum trained fanner $(50 \%)$ were facing problems of marketing, followed by maximum trained fanners $(42.5 \%)$ were facing problem non availability of D.A.P. followed by maximum trained farmer $(43.75 \%)$ were facing problems un assured irrigation and maximum as farmer $(25 \%)$ were facing problem of storage.

\section{Measure from the removal of the problem recommended practices of wheat crop}

Table.2 Suggestion made for removal of problem recommended practices of wheat crop

\begin{tabular}{|l|l|c|c|}
\hline Sl.No. & Particulars & $\begin{array}{c}\text { No. of } \\
\text { respondents }\end{array}$ & Percentage \\
\hline 1. & training required before crop season & 53 & 66.25 \\
\hline 2. & Government subsidy on store wine & 40 & 50.00 \\
\hline 3. & Proper training should be made at block level & 35 & 43.75 \\
\hline 4. & Non bank loan should be easily available & 36 & 45.00 \\
\hline 5. & $\begin{array}{l}\text { Fertilizer should be made available block } \\
\text { store }\end{array}$ & 32 & 40 \\
\hline 6. & Assured irrigation & 30 & 37.5 \\
\hline 7. & Government should fixed oil purchase & 25 & 31.25 \\
\hline 8. & Rate of interest should be minimised & 24 & 17.5 \\
\hline 9. & $\begin{array}{l}\text { Expenditure should be minimized with } \\
\text { government subsidy }\end{array}$ & 14 & \\
\hline
\end{tabular}

It is evident from the table 2 that "training requirement before crop session" was the first and important - suggestion the percentage of this statement $(66.25 \%)$ in order of preference of the next is "subsidy on government subsidy on store wine" the percentage of this suggestion $(50 \%)$ that was followed by "proper training should be made at block level the percentage of this statement is $(43.75 \%)$ the next one was "non bank loan should be easily available" the percentage of this suggestion is $(45 \%)$ of the next one was "fertilizer should be made available block store" the percentage value of this suggestion i.e. $40 \%$ the next one was "assured irrigation" the percentage of this suggestion is $(37.5 \%)$ the next one was "Government should fix oil purchase until " the percentage of the suggestion is $(31.25 \%)$ in order to preference the next " rate of interest should be minimised" the percentage of this suggestion is $(31.25 \%)$ and the next one was "expenditure should be minimised with the government subsidy" the mean value of this suggestion is $(17.5 \%)$. It is clear from the above result that "training required before crop session" "subsidy on government subsidy on store wine" proper training should be made non bank loan easily available, "fertilizer should be made available at block level should be easily store" "irrigation assured irrigation" government should fixed oil purchases" "rate of interest should be minimised with government subsidy", were the most important suggestion made by the beneficiaries of the K.V.K. 
In conclusion, on the basis of the above findings of the research, it can be concluded that most of the farmer were having fair and good level of knowledge about wheat production technology while they had poor level of knowledge about plant protection practices in wheat crop. In case of adoption majority of the farmers were having medium and high level of adoption except seed treatment, plant protection practices of wheat crop.

Poor level of knowledge and less profitable technology were the major problems which create hindrances for adoption of wheat production technology.

\section{How to cite this article:}

Vijay Kumar Verma, O.P. Yadav, A.K. Singh and Rajmani. 2017. Problems of KVK (Krishi Vigyan Kendra) Beneficiaries in Adoption of Recommended Production of Wheat Crop. Int.J.Curr.Microbiol.App.Sci. 6(8): 1064-1067. doi: https://doi.org/10.20546/ijcmas.2017.608.132 